\title{
The Life Hidden Inside Caves: Ecological and Economic Importance of Bat Guano
}

\author{
Souraya Sakoui $\mathbb{D}^{1},{ }^{1}$ Reda Derdak $\left(\mathbb{D},{ }^{1}\right.$ Boutaina Addoum $\left(\mathbb{D},{ }^{1}\right.$ Aurelio Serrano-Delgado $\left(\mathbb{D},{ }^{2}\right.$ \\ Abdelaziz Soukri, ${ }^{1}$ and Bouchra El Khalfi $\left(\mathbb{1}^{1}\right.$ \\ ${ }^{1}$ Laboratory of Physiopathology, Molecular Genetics \& Biotechnology, Faculty of Sciences Ain Chock, \\ Health and Biotechnology Research Center, Hassan II University of Casablanca, B.P. 5366 Maarif, Casablanca, Morocco \\ ${ }^{2}$ Institute for Plant Biochemistry and Photosynthesis (IBVF), CSIC-Universidad de Sevilla, Seville, Spain \\ Correspondence should be addressed to Bouchra El Khalfi; bouchra.elkhalfi@gmail.com
}

Received 20 January 2020; Revised 5 May 2020; Accepted 25 May 2020; Published 19 November 2020

Academic Editor: Ram Chander Sihag

Copyright $\odot 2020$ Souraya Sakoui et al. This is an open access article distributed under the Creative Commons Attribution License, which permits unrestricted use, distribution, and reproduction in any medium, provided the original work is properly cited.

Bats are emblematic hosts of caves. These small flying mammals deserve special attention because their presence has a great economic and ecological impact; they introduce organic matter, the guano, in the ecosystem they live in. Indeed, "guano" (a Quechua word meaning "fertilizer") is the accumulation of their fecal matter (excreta); its deposition can reach several meters. The composition of guano is influenced by the bat's food. In addition to its role within the caves, the bat guano is exploited for various purposes; it is used as an effective fertilizer for the cultivation of plants because of having exceptionally high content of nitrogen, phosphate, and potassium and also for the improvement of detergents and other products of great value for humans. The bat guano hosts various classes of microorganisms (viruses, bacteria, algae, fungi, and protists), which are adapted to the cave environment. Since guano is highly acidic, these microorganisms can be considered as extremophiles. They produce functional organic compounds in extreme conditions that could be of interest not only in the drug industry but also in different biotechnological areas. Here, we review already available information on the ecological and economic effects of bats and their guano. We report their food preferences, foraging behaviors, and environmental impacts. Information on these aspects may be useful in finding a solution about protection and preservation of bat populations.

\section{Introduction}

The order Chiroptera (of the bats) is the second most diverse among all the orders of mammals, which presents a great ecological and physiological diversity. Bats evolved 52 million years ago and enlarged into more than 1,232 existing species [1]. They are an integral part of the environment and have ecological and economic importance for humans [2]. Insectivorous bats help suppress the natural and anthropogenic pathogenic insects, whereas frugivorous bats help conserve forest diversity by dispersing seeds in different ecosystems and often introduce new plant species [3]. The guano of these small mammals can provide nutrients and energy to the terrestrial and aquatic ecosystems. But, in recent years, many anthropogenic activities, such as destruction of forests and other terrestrial ecosystems, the disruption of caves, depletion of food resources, and overuse of pesticides, contributed to the unintentional killing of bats [4].

In the present article, we provide an overview about the mode of life of bats, the direct or indirect benefits they bring to the environment, and importance of preserving the bats. We zoom in on the bat guano, which is characterized by its rich mineral composition and having a diversity of microorganisms that can be exploited for use in various fields.

\section{Bats}

Bats are emblematic hosts of caves. They constitute a diverse group of mammals belonging to the order Chiroptera, which colonizes all the terrestrial ecosystems, except the polar regions and some oceanic islands. They form a huge 
nonhuman aggregation and are the most abundant mammals in terms of number of individuals. Nearly 1,232 species of bats have been identified worldwide, which means that one in five (21\%) mammal species is a bat [1]. The bats have variable weights ranging from $2 \mathrm{~g}$ of the smallest Craseonycteris thonglongyia to $1.6 \mathrm{~kg}$ of the largest Pteropus giganteus [2].

Analysis of fecal matter of bats allows identification of their great dietary diversity $[5,6]$. There are insectivorous, frugivorous, herbivorous, nectarivorous, and even sanguivorous (blood eating) bats (vampires) [7].

Globally, about $70 \%$ of bats are insectivorous [8]. They are among the biggest predators of flying insects (Figure 1) and prove to be valuable pest management agents in natural and man-made ecosystems. They eat large numbers of lepidopterous (butterflies), coleopterous (beetle), dipterous (flies), homopterous (cicadas and leafhoppers), and hemipterous (true bugs) insects $[10,11]$.

The size of the prey can vary from $1 \mathrm{~mm}$ (midges and mosquitoes) to $50 \mathrm{~mm}$ long (beetles and large mites) depending on the species of bat. Bats often eat all the night and then return to their roosts to nurse and rest during periods of low insect activity [12].

On the contrary, herbivorous bats feed on various segments of plants, including flowers, pollen, nectar, leaves, and fruits. Bats which feed on fruits are called frugivores, and they are generally abundant in secondary forests $[13,14]$ due to the high production of fruit plants characteristic of these ecosystems (e.g., Piper and Cercopia) [15] (Figure 2).

Bats are nocturnal animals. Although they may see well, yet many bats have a sonar system-based strategy called echolocation to find their preys, avoid obstacles, and locate their roosting in the dark $[16,17]$. Echolocation in bats is their capacity to release a series of acute cries (sonar) with their mouth or nose (Figure 3). This enables them to locate, move, and hunt their prey, having information on the direction, distance, size, and even texture of the insect [18].

2.1. Lifestyle. Bats inhabit a wide range of roosts, such as deserted mines, caves, and tree-related microhabitats such as cavities, crevices in trunks, and branches, to rest and breed. Caves are especially considered as an ideal habitat for heterothermic bat species, mainly to breed and hibernate $[19,20]$.

In winter, some bats migrate south to search for their food, while others hibernate when insects are hard to find. Bats travel generally less than 200 miles, following the same itinerary and path as migratory birds do [21]. Bats can also move from nursery caves adapted to the rapid growth of their young to cooler caves with stable temperatures in winter [22].

When a bat hibernates, its metabolism, body temperature, breathing, and heart rate decrease. The muscle tissue of hibernating bats shows a significant decline in oxidative potential, no change in glycolytic potential, and no alteration in fibre composition. Throughout hibernation, bats do not eat, rather they survive by slowly burning fat accumulated during the summer [19].

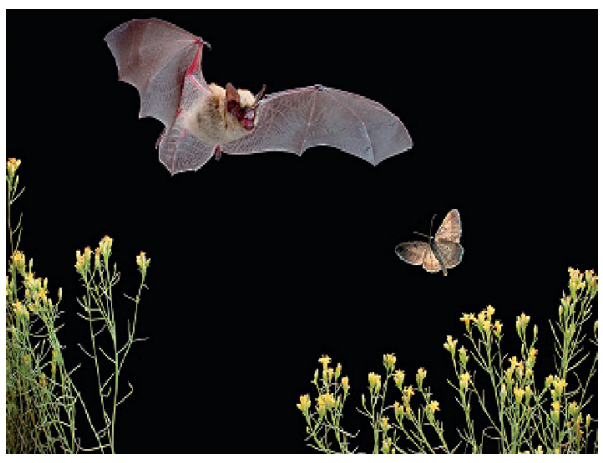

Figure 1: Insectivorous bat (photo by Bruce D Taubert, Bat Conservation International, http://www.batcon.org) [9].

Bats live exceptionally longer than other mammals of their size. Such comparison supports Rubner's hypothesis (1908) that asserts that the metabolic rate is a determinant of longevity [23]. Although there is a positive correlation between mammalian species size and longevity, Chiroptera do not initially appear to conform to this trend. This apparent anomaly can be explained by considering that the metabolic rate of the bat is often reduced to low levels. In fact, bats not only reduce metabolic rates during hibernation but they are also able to reduce their daily physiological/metabolic levels when they are at rest $[19,21]$.

2.2. The Importance of Bats. Bats have since long played a crucial role in several fields. They play a key role in agriculture [12]. They are major benefactors to crop pollination and seed dispersal. They are also excellent ecological indicators of good quality of habitat [24].

Their presence in the caves has a modifying impact that was since long unknown. Bats mark their presence by physical alterations of rocks which they cling to with their claws, chemical alterations due to the large amounts of urine they generate which is corrosive, and gaseous alterations by breathing, leading to significant production of carbon dioxide $\left(\mathrm{CO}_{2}\right)[25]$.

\section{Bat Guano}

The bat guano is defined as the excreta of bats. In the habitat where bats aggregate, it is produced in large amounts, actually in tons (Figure 4). Importance of the bat guanos has been studied from a mineralogical point of view. These are the biowastes of the cave ecosystems and are rich in minerals [27].

The bat guano is essentially composed of phosphates and sulphates of potassium, ammonium, sodium, magnesium, and calcium [28]. Phosphorus, aluminium, and iron are generally found in the upper layers of the guano. Calcium comes from carbonate rocks, cavity walls, or ceilings, while iron and aluminium come from the interaction of phosphates and clays, causing their decomposition. However, its composition also varies according to the diet of the bat species. Earlier study on the environmental history of a bat guano deposit showed the difference in appearance, color, 


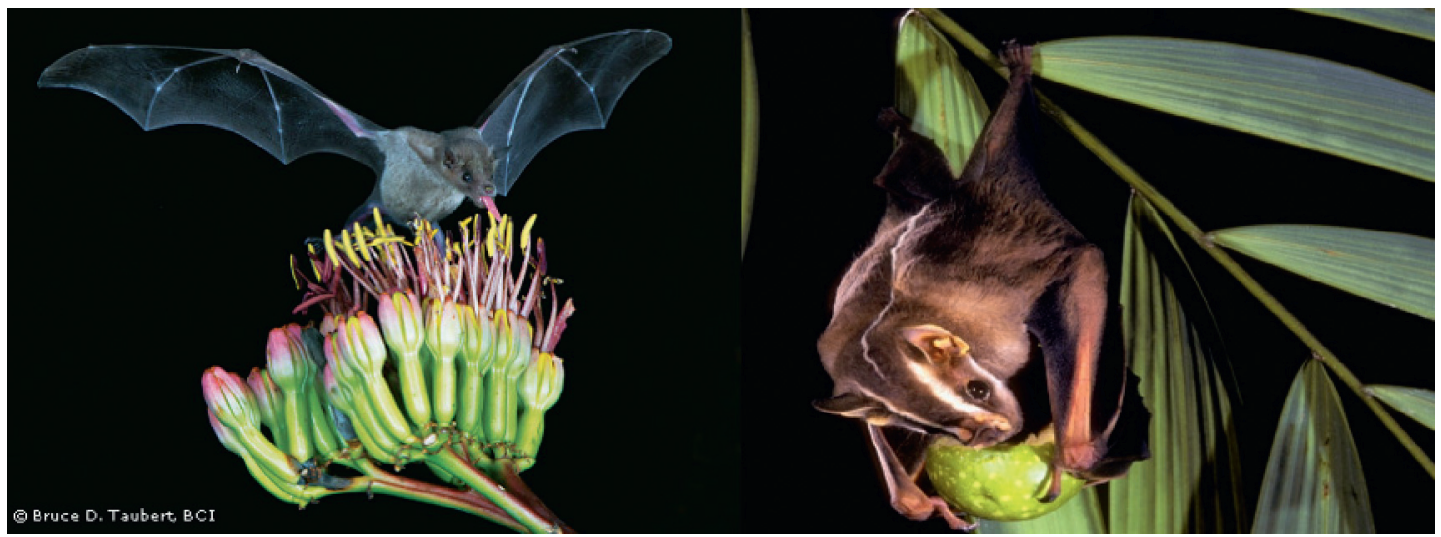

Figure 2: Bats visiting plants (source: Bat Conservation International, http://www.batcon.org) [9].

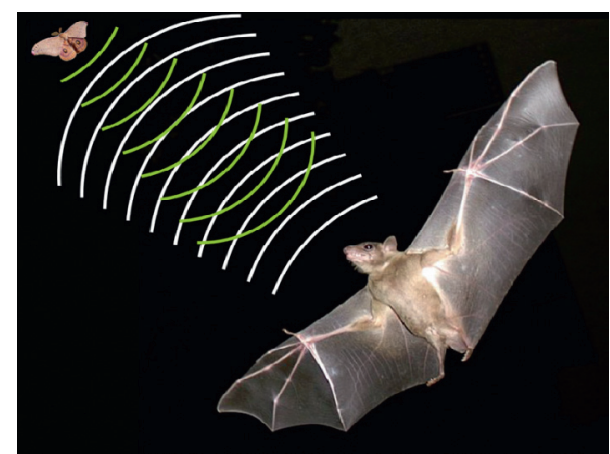

FIGURE 3: Navigation and prey identification by a bat through echolocation. Source: Rendall, BMC Biology 2013 [18].

and chemical composition of guano in different depths up to $150 \mathrm{~cm}$ (Figure 4) [26].

Knowing that the bat guano contains about 25\% of phosphate, the amount of phosphate salts generated can be estimated. For a period of 1,000 years, 10 individuals of Plecotus auratus and 10 individuals of Myotis daubentonii, who would have occupied a cavity for four months per year, can generate approximately $65 \mathrm{~kg}$ of phosphate salts [27]. The bat guano also carries high levels of nitrogen, about $5-10 \%$ including $80 \%$ of uric acid.

The levels of phosphates contained in the bat guano of insectivorous and frugivorous Chiroptera are very high [27] and show important variations $[28,29]$. Furthermore, the $\mathrm{pH}$ of the bat guano varies not only with age and storage conditions but also with the diet of bats (Table 1) [29].

All this makes the bat guano an acidic and/or extremely saline environment, which determines many of its physicochemical and microbiological characteristics.

The bat guano should be harvested under the right conditions and must be sustainable [30, 31]. A poorly managed harvest can disrupt bats and the latter may desert caves. In this context, IUCN has set standards for the bat guano harvest to minimize the negative impact on bats and other organisms of caves [30]. A further study, based on the IUCN guidelines, was able to demonstrate that if the harvest rate does not exceed the deposit rate of guano, this does not affect the population of bat [32].
3.1. The Role of the Bat Guano in Caves. The bat guano plays significant roles in the caves. It contributes to the renewal of the main organic resources of the caves and allows the development of a varied biota (bacteria, fungi, protists, and small arthropods (including insects, myriapods, and spiders) $[12,33]$ (Figure 5). It is the main food resource for this specific microcosm. In addition, the fermentation of this biomass constitutes, with the presence of the bat colonies, a source of heat production inside the caves [35].

Moreover, the bat guano is the sediment that records the contemporary environmental parameters of its constituents (pollen, insect remains, isotopes, etc.), just like speleothems. The role of the guano acidity in corrosion has long been suggested in earlier report [25].

When water drips through this guano, the ammonium is released. However, orthophosphate $\left(\mathrm{PO}_{4}{ }^{3}\right)$, which is less soluble, remains in place. The leaching by percolation of water first eliminates ammonia and later on nitrates. Eventually, this phenomenon produces acid solutions that can reach a very low $\mathrm{pH}$, between 2 and 4 [36]. These corrosive solutions then react with the calcium carbonate of the host substrate or speleothems and form phosphate minerals, mainly hydroxyapatite $\left[\mathrm{Ca}_{5}\left(\mathrm{PO}_{4}\right)_{3}(\mathrm{OH})\right]$. Depending on the chemical elements present in the guano or in the bedrock, various reactions can take place and give birth to a whole mineralogy. This neogenesis can also reach the sediments under the guano [25].

3.2. Economic Importance. Bat guano has been extracted from caves since a long time to be used as a fertilizer for agricultural crops due to the presence of high concentration of limiting nutrients such as nitrogen and phosphorus [37]. Prices for the organic bat guano fertilizer ranged from $\$ 1.25$ to $\$ 12.00$ per $0.5 \mathrm{~kg}$. The guano of the Mexican free-tailed bat has been extracted to produce fertilizer in thousands of tons in the only cave in Bracken, Texas. Retail sales currently range from $\$ 2.86$ to $\$ 12.10$ per $\mathrm{kg}$ [2]. It provides one of the best natural fertilizers worldwide [37].

In Cambodia, growth trials were conducted on five economically important plant species of the country: horseradish (Moringa oleifera Lam.), Jack fruit (Artocarpus heterophyllus Lam.), Longan (Dimocarpus longan Lour.), Eggplant (Solanum melongena L.), and papaya (Carica 


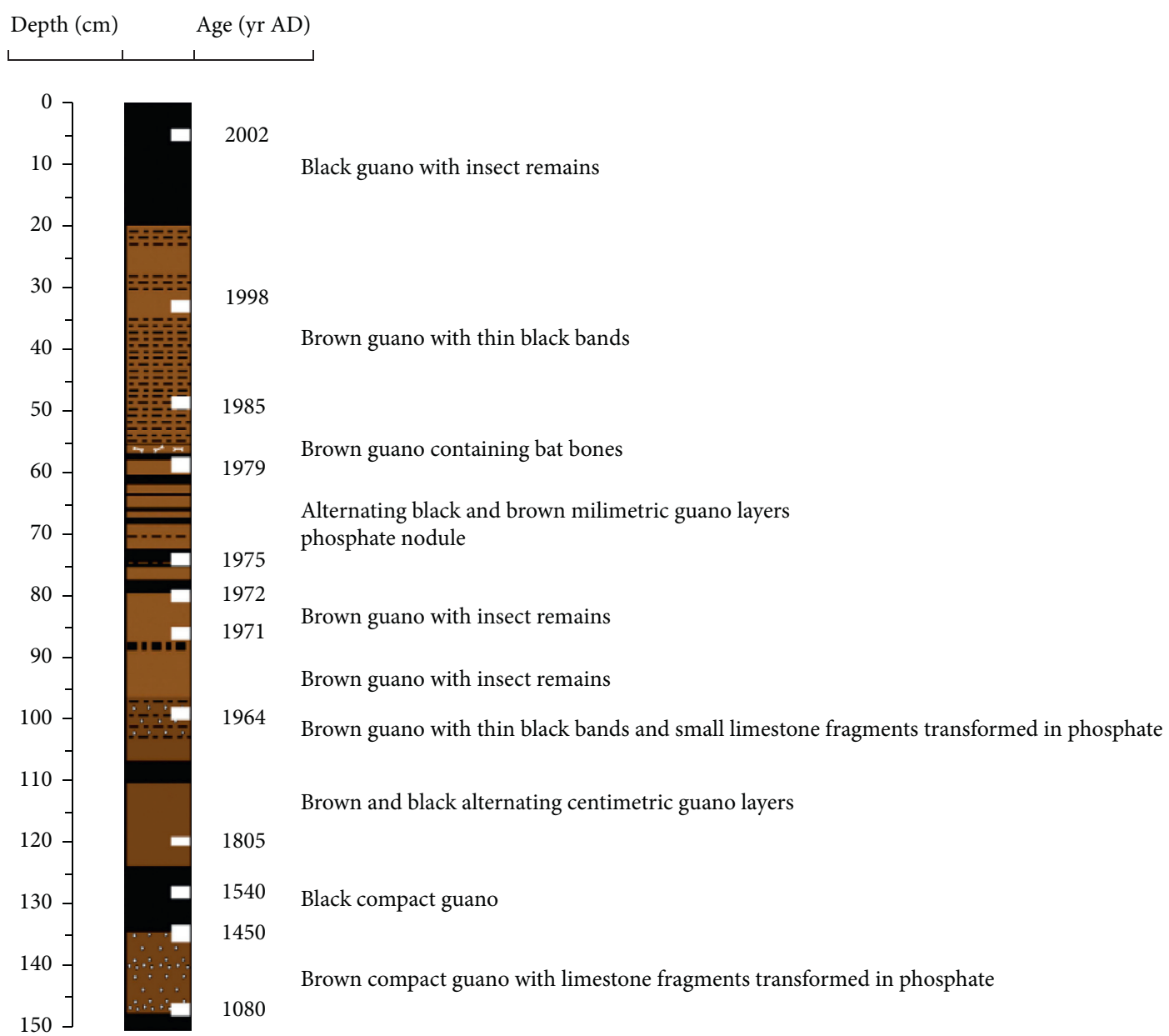

FIgURE 4: Stratigraphy of the bat guano nucleus showing the radiocarbon samples (white rectangles) and their calibrated ages [26].

TABle 1: Phosphate and $\mathrm{pH}$ levels of guano from bats fed with different diets [28].

\begin{tabular}{lcc}
\hline Nutritional regimen & Phosphate $(\%, w / w)$ & $\mathrm{pH}$ \\
\hline Frugivore & $5.1-7.7$ & Neutral to alkaline \\
Insectivore & $25-57$ & Acid \\
\hline
\end{tabular}

papaya L.), it was and reported that the bat guano applications notably improved plant growth [37]. Compared to controls, all the guano-treated plant species exhibited higher growth rates, most of which were statistically significant compared to chemical fertilizer treatments [37].

It has also been reported that the bat guano can be considered as an alternative source of chitin and chitosan [38]. The latter are obtained normally from the exoskeleton of crustaceans, such as shrimps and crabs, and have a wide range of applications in several fields, such as cosmetics, pharmacy, medicine, bioengineering, agriculture, textile, and environmental engineering, due to their nontoxic, ecological, biocompatible, and biodegradable properties [39].

3.3. Ecological Importance. The bat guano provides primary organic input to cave ecosystems, which are intrinsically devoid of primary productivity because of the absence of light; the latter condition impedes the presence of photoautotrophic organisms [2]. It hosts a diversity of organisms that differ depending on the species of bats and their diets. For example, small metazoans such as mites, pseudoscorpions, beetles, thrips, mites, and flies inhabit the guano of insectivorous bats, whereas the guano of frugivorous bats is frequented by spiders, mites, isopods, millipedes, centipedes, waders, barklice, and insects. Salamander and cavefish populations and invertebrate communities also rely heavily on nutrients from the bat guano [1].

The bat guano also constitutes a niche of several varieties of microorganisms, including fungi, protists, lichens, viruses, and bacteria [40, 41].

\section{Bacteria in the Bat Guano}

Recent genomic studies have focused on the study of bacterial taxa found in the specific bat tissues and isolated from the bat guano. These bacterial communities may vary according to several criteria, including the state and age of the guano and the diet of the bat [42]. When decomposed, guano has greater bacterial diversity than when it is fresh. This was demonstrated by a study that aimed to identify potential bacterial functions performed within the bat guano at different depths. Although similar taxa occur in all the guano states, relative abundances 


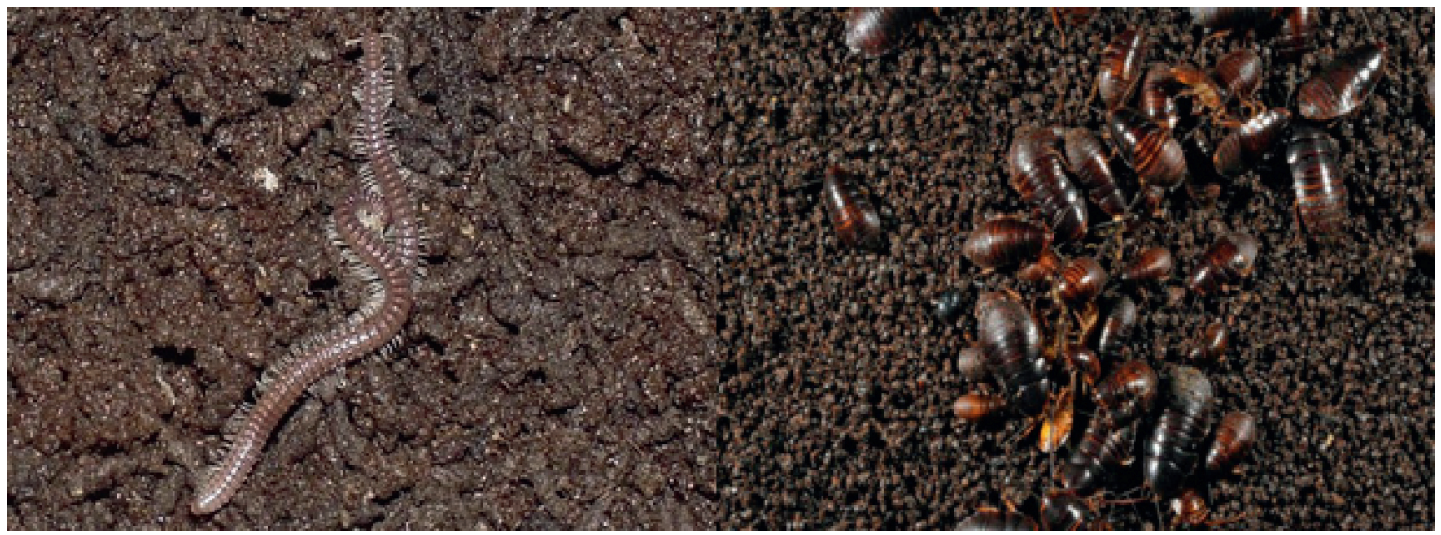

FIGURE 5: Cave arthropods, cockroaches, and centipedes on bat guano (source: Robbie Shone) [34].

allow some taxa (mainly Proteobacteria and Actinobacteria) to dominate the bacterial community at different depths. For example, Pantoea vagans, Staphylococcus lugdunensis, Weissella confusa, and Streptomyces cremeus were identified from fresh guano; Lactococcus garvieae, Enterobacter asburiae, and Lactococcus lactis were from superficial guano, while Microbacterium oxydans, Enterococcus faecalis, Microbacterium maritypicum, Bacillus safensis, and Bacillus velezensis are abundant in all the states of guano [43]. On the contrary, De Mandal et al. [44] studied the decomposition of guano and reported a large abundance of bacterial communities involved in the nitrogen biogeochemical cycle [44]. This bacterial community variation in different guano samples may be accompanied by a difference in the composition of the major elements and trace elements. As De Leon et al. [45] compared the guano bacterial communities from two different regions, one of these guanos presented high levels of $\mathrm{Si}, \mathrm{Fe}, \mathrm{Mg}, \mathrm{Al}, \mathrm{Mn}$, $\mathrm{Ti}$, and $\mathrm{Cu}$, which was dominated by Proteobacteria $(61.7 \%)$, Actinobacteria (19.4\%), Bacteroidetes (4.2\%), Firmicutes (2.7\%), Chloroflexi (2.5\%), and phylum candidate TM7 (2.3\%), while the second guano showed high concentrations of $\mathrm{Ca}, \mathrm{P}, \mathrm{S}, \mathrm{Zn}$, and $\mathrm{Cr}$ and was almost entirely dominated by Proteobacteria (61.7\%) and Actinobacteria (34.9\%) [45].

Other studies have shown that the bat guano may contain potentially pathogenic bacteria such as Burkholderia, Corynebacterium, Francisella, Legionella, Mycobacterium, Pseudomonas, Yersinia, Campylobacter, and Rickettsia [42]. This suggests that the bat guano could be a source of potentially harmful pathogenic microorganisms for humans and animals. Frequent intra- and interpopulation movements and bat migrations over long distances strengthen the potential for bacterial transmission between individuals of different geographic areas and the possibility of potential hazards to occur worldwide. The presence of beneficial bacteria in bats, such as probiotics, can provide vital benefits to their hosts, such as the treatment of skin infections, the release of fatty acids to reduce the invasion of transient microorganisms, and inhibition of pathogenic microorganisms. These beneficial bacteria include lactic acid bacteria, such as Leuconostocaceae, Enterococcaceae, and Streptococcaceae [43].
In addition to the decomposition state of the guano, the bat diet and some of their seasonal and behavioral activities also affect the bacterial community. The guano of herbivorous and reproductively active bats carries a more varied microbiota than carnivorous bats and reproductively inactive individuals [42].

Several studies of bacterial isolation and identification in the bat guano suggest that it can constitute a considerable number of bacterial species. Despite previous reports of bacterial identification in the bat guano or their intestinal contents, there remains an immense field of identification of other possibly novel bacterial species. Therefore, there is a serious need for study of guano-associated bacteria.

\section{Eukaryotic Microbes in the Bat Guano}

Although not as thoroughly studied as bacteria, phylogenetically diverse eukaryotic microorganisms (fungi and protists) have been described and isolated from the bat guano $[43,46,47]$. This fungal biodiversity is due to the very specific and stable microclimate of the caves. These fungi have attracted the attention of mycologists because of their medical potential, as well as their important role as an essential link in the trophic chain within the cave. The study of these fungi is also important due to their ability to produce mycotoxins [46].

Guanophilic zygomycetes fungi such as Circinella umbellata (Mucorales) predominate in the bat guano, but basidiomycetes species (e.g., Ganoderma sp., Geastrum sp., Lepiota sp., Polyporus sp., and Ramaria sp.) and ascomycetes species (Hypoxylon sp., Xylaria anisospleura, and $X$. kegeliana) are also frequently found [48]. Heterotrophic protists have been very poorly researched in caves. Saprophytic amoebas and diatoms are found in substrates rich in organic matter such as bat's guano. The cosmopolitan phycobiliprotein-containing microalgae of the order Cyanidiales, e.g., Cyanidium sp. and Galdieria sp., are acidophilic unicellular Rhodophyta found in caves over the world in places with dim light (near the cave entrances) and can benefit from guano by their extremely versatile mixotrophic metabolism [49]. 


\section{Conclusion}

Caves are underground chambers that can take hundreds of thousands of years to form. They are considered as an extreme ecosystem, which are inhabited by a wide range of organisms and microorganisms. Bats are an integral part of this ecosystem which provides an important role in different fields directly and indirectly by the production of the guano. The latter plays several roles within the cave by contributing as an organic matter; it is also exploited in the improvement of different products of great value for humans such as detergents. At present, data on the economic and ecological value of bats and the bat guano for the ecosystems and humans are limited. Therefore, there is a need for more indepth assessments to enhance and fulfill our knowledge about these mammals, especially to examine why the various forms of this group of mammals deserve protection and conservation. Taking into account its numerous benefits, future research is needed to identify the extremophilic microorganisms inhabited by the bat guano and their possible application in biotechnology.

\section{Conflicts of Interest}

All the authors declare that there are no conflicts of interest.

\section{References}

[1] T. H. Kunz, E. Braun de Torrez, D. Bauer, T. Lobova, and T. H. Fleming, "Ecosystem services provided by bats," Annals of the New York Academy of Sciences, vol. 1223, no. 1, pp. 1-38, 2011.

[2] M. Kasso and M. Balakrishnan, "Ecological and economic importance of bats (order chiroptera)," ISRN Biodivers, vol. 2013, Article ID 187415, 9 pages, 2013.

[3] D. H. Kelm, K. R. Wiesner, and O. V. Helversen, "Effects of artificial roosts for frugivorous bats on seed dispersal in a neotropical forest pasture mosaic," Conservation Biology, vol. 22, no. 3, pp. 733-741, 2008.

[4] S. Mickleburgh, K. Waylen, and P. Racey, "Bats as bushmeat: a global review," Oryx, vol. 43, no. 2, pp. 217-234, 2009.

[5] T. H. Kunz and J. O. Whitaker Jr., "An evaluation of fecal analysis for determining food habits of insectivorous bats," Canadian Journal of Zoology, vol. 61, no. 6, pp. 1317-1321, 1983.

[6] A. Beck, "Fecal analysis of european bat species," Myotis, vol. 32-33, pp. 109-119, 1995.

[7] L. F. Rodrigo and R. P. Martins, "Diversity and distribution of spiders associated with bat guano piles in morrinho cave (Bahia state, Brazil)," Diversity and Distributions, vol. 4, no. 5, pp. 235-241, 1998.

[8] E. Alleva, N. Francia, M. Pandolfi, A. M. De Marinis, F. Chiarotti, and D. Santucci, "Organochlorine and heavymetal contaminants in wild mammals and birds of urbinopesaro province, Italy: an analytic overview for potential bioindicators," Archives of Environmental Contamination and Toxicology, vol. 51, no. 1, pp. 123-134, 2006.

[9] Important, http://www.batcon.org/why-bats/bats-are/batsare-important.

[10] P. W. Freeman, "Correspondence of food habits and morphology in insectivorous bats," Journal of Mammalogy, vol. 62, no. 1, pp. 166-173, 1981.
[11] B. Law, K. J. Park, and M. J. Lacki, "Insectivorous bats and silviculture: balancing timber production and bat conservation," in Bats in the Anthropocene: Conservation of Bats in a Changing World, pp. 105-150, Springer International Publishing, Berlin, Germany, 2015.

[12] J. G. Boyles, P. M. Cryan, G. F. McCracken, and T. H. Kunz, "Economic importance of bats in agriculture," Science, vol. 332, no. 6025, pp. 41-42, 2011.

[13] S. Oporto, S. L. Arriaga-Weiss, and A. A. Castro-Luna, "Diversidad y composición de murciélagos frugívoros en bosques secundarios de Tabasco, México," Revista Mexicana de Biodiversidad, vol. 86, no. 2, pp. 431-439, 2015.

[14] A. G. da Silva, O. Gaona, and R. A. Medellín, "Diet and trophic structure in a community of fruit-eating bats in lacandon forest, méxico," Journal of Mammalogy, vol. 89, no. 1, pp. 43-49, 2008.

[15] P. E. D. Bobrowiec and R. Gribel, "Effects of different secondary vegetation types on bat community composition in Central Amazonia, Brazil," Animal Conservation, vol. 13, no. 2, pp. 204-216, 2010.

[16] G. Jones and E. Teeling, "The evolution of echolocation in bats," Trends in Ecology \& Evolution, vol. 21, no. 3, pp. 149-156, 2006.

[17] E. C. Teeling, M. Scally, D. J. Kao, M. L. Romagnoli, M. S. Springer, and M. J. Stanhope, "Molecular evidence regarding the origin of echolocation and flight in bats," Nature, vol. 403, no. 6766, pp. 188-192, 2000.

[18] D. Rendall, "Q\&A: cognitive ethology-inside the minds of other species," BMC Biology, vol. 11, no. 1, 2013.

[19] B. Regnery, D. Couvet, L. Kubarek, J.-F. Julien, and C. Kerbiriou, "Tree microhabitats as indicators of bird and bat communities in Mediterranean forests," Ecological Indicators, vol. 34, pp. 221-230, 2013.

[20] R. K. Lučan, V. Hanák, and I. Horáček, "Long-term re-use of tree roosts by European forest bats," Forest Ecology and Management, vol. 258, no. 7, pp. 1301-1306, 2009.

[21] I. Gottfried, T. Gottfried, and K. Zając, "Bats use larval galleries of the endangered beetle Cerambyx cerdo as hibernation sites," Mammalian Biology, vol. 95, pp. 31-34, 2019.

[22] P. Cryan and J. Veilleux, "Migration and the use of autumn, winter, and spring roosts by tree bats," 2007, https://pubs.er. usgs.gov/publication/70180873.

[23] C. F. Herreid, "Bat longevity and metabolic rate," Experimental Gerontology, vol. 1, no. 1, pp. 1-9, 1964.

[24] U. Hassi, "Importance of bats (order Chiroptera) in agricultural services," Journal of Plant Sciences and Crop Protection, vol. 1, no. 2, pp. 14-16, 2018.

[25] P. Audra, L. Barriquand, J. Bigot, D. Cailhol, and H. Caillaud, "L'impact méconnu des chauves-souris et du guano dans l'évolution morphologique tardive des cavernes," 2016, https://hal.archives-ouvertes.fr/hal-01838348/.

[26] F. L. Forray, B. P. Onac, I. Tanţău, J. G. Wynn, T. Tămaş, I. Coroiu et al., "A Late Holocene environmental history of a bat guano deposit from Romania: an isotopic, pollen and microcharcoal study," Quaternary Science Reviews, vol. 127, pp. 141-154, 2015.

[27] A. Giurgiu and T. Tămaş, "Mineralogical data on bat guano deposits from three Romanian caves," Studia Universitatis Babes-Bolyai, Geologia, vol. 58, no. 2, pp. 13-18, 2013.

[28] S. R. Shahack-Gross, F. Berna, P. Karkanas, and Weiner, "Bat guano and preservation of archaeological remains in cave sites," Journal of Archaeological Science, vol. 31, no. 9, pp. 1259-1272, 2004. 
[29] J. K. Emerson and A. M. Roark, "Composition of guano produced by frugivorous, sanguivorous, and insectivorous bats," Acta Chiropterologica, vol. 9, no. 1, pp. 261-267, 2007.

[30] International Union for Conservation of Nature, "Guidelines for minimizing the negative impact to bats and other cave organisms from guano harvesting," International Union for Conservation of Nature, Gland, Switzerland, 2014.

[31] N. Furey, T. Whitten, J. Cappelle, and P. Racey, "The conservation status of Cambodian cave bats," International Speleological Project to Cambodia, vol. 64, pp. 82-95, 2016.

[32] K. M. Mya and T. Thet, "Harvesting the guano of insectivorous bats: is it sustainable," Journal of Threatened Taxa, vol. 7, no. 6, pp. 7296-7297, 2015.

[33] R. P. Ferreira and R. L. Martins, "Diversity and distribution of spiders associated with bat guano piles in Morrinho cave (Bahia State, Brazil)," Diversity and Distributions, vol. 4, pp. 235-241, 1998.

[34] Cave Cockroaches on Bat Guano Photograph by Robbie Shone, https://fineartamerica.com/featured/1-cave-cockroaches-onbat-guano-robbie-shone.html.

[35] A. G. Popa-Lisseanu, A. Delgado-Huertas, M. G. Forero, A. Rodríguez, R. Arlettaz, and C. Ibáñez, "Bats' conquest of a formidable foraging niche: the myriads of nocturnally migrating songbirds," PLoS One, vol. 2, no. 2, 2007.

[36] J. Mulec, E. Dietersdorfer, M. Üstüntürk-Onan, and J. Walochnik, "Acanthamoeba and other free-living amoebae in bat guano, an extreme habitat," Parasitology Research, vol. 115, no. 4, pp. 1375-1383, 2016.

[37] T. Sothearen, N. M. Furey, and J. A. Jurgens, "Effect of bat guano on the growth of five economically important plant species," Journal of Tropical Agriculture, vol. 52, no. 2, pp. 169-173, 2014.

[38] H. Rahmawati, A. J. Purnomo, S. Umniyatie, and D. Pramiadi, "Identification and characterization of chitinase enzyme producing bacteria from bat guano and its potential to inhibit the growth of fungus colletotrichum sp. Cause anthracnose on the chili by in vitro," International Journal of Advances in Agricultural and Environmental Engineering, vol. 3, no. 2, pp. 1-6, 2016.

[39] M. Kaya, O. Seyyar, T. Baran, and T. Turkes, "Bat guano as new and attractive chitin and chitosan source," Frontiers in Zoology, vol. 11, no. 1, 2014.

[40] E. M. Adetutu and A. S. Ball, "Microbial diversity and activity in caves," Microbiology Australia, vol. 35, no. 4, p. 192, 2014.

[41] S. Wacharapluesadee, C. Sintunawa, T. Kaewpom et al., "Group C betacoronavirus in bat guano fertilizer, Thailand," Emerging Infectious Diseases, vol. 19, no. 8, pp. 1349-1351, 2013.

[42] S. Banskar, D. T. Mourya, and Y. S. Shouche, "Bacterial diversity indicates dietary overlap among bats of different feeding habits," Microbiological Research, vol. 182, pp. 99-108, 2016.

[43] M. M. Newman, L. N. Kloepper, M. Duncan, J. A. McInroy, and J. W. Kloepper, "Variation in bat guano bacterial community composition with depth," Frontiers in Microbiology, vol. 9, 2018.

[44] S. De Mandal, Zothansanga, A. K. Panda, S. S. Bisht, and N. Senthil Kumar, "First report of bacterial community from a Bat Guano using Illumina next-generation sequencing," Genomics Data, vol. 4, pp. 99-101, 2015.

[45] M. P. De Leon, A. D. Montecillo, D. S. Pinili, M. A. T. Siringan, and D.-S. Park, "Bacterial diversity of bat guano from Cabalyorisa Cave, Mabini, Pangasinan,
Philippines: a first report on the metagenome of Philippine bat guano," PLoS One, vol. 13, no. 7, 2018.

[46] S. R. Joshi and U. Chettri, "Fungi in hypogean environment: bioprospection perspective," in Advancing Frontiers In Mycology \& Mycotechnology, pp. 539-561, Springer, Singapore, 2019.

[47] M. Vaughan, R. Maier, and B. Pryor, "Fungal communities on speleothem surfaces in Kartchner caverns, Arizona, USA," International Journal of Speleology, vol. 40, no. 1, pp. 65-77, 2011.

[48] Á. Nieves-Rivera, C. Santos-Flores, F. Dugan, and T. Miller, "Guanophilic fungi in three caves of southwestern Puerto Rico," International Journal of Speleology, vol. 38, no. 1, pp. 61-70, 2009.

[49] L. Hoffmann, "Cyanidium-like algae from caves," in Evolutionary Pathways and Enigmatic Algae: Cyanidium Caldarium (Rhodophyta) and Related Cells, pp. 175-182, Springer, Netherlands, 1994. 